\title{
Antibacterial effect of plant-derived antimicrobials on major bacterial mastitis pathogens in vitro
}

\author{
S. Ananda Baskaran, ${ }^{*}$ G. W. Kazmer, ${ }^{*}$ L. Hinckley,† S. M. Andrew, ${ }^{*}$ and K. Venkitanarayanan ${ }^{* 1}$ \\ ${ }^{*}$ Department of Animal Science, Unit-4040, and \\ †Department of Pathobiology, Unit 4089, University of Connecticut, Storrs 06269
}

\begin{abstract}
The objective of this study was to investigate the antimicrobial effect of plant-derived antimicrobials including trans-cinnamaldehyde (TC), eugenol, carvacrol, and thymol on major bacterial mastitis pathogens in milk. The minimum inhibitory concentration (MIC) and minimum bactericidal concentration (MBC) of the aforementioned compounds on Streptococcus agalactiae, Streptococcus dysgalactiae, Streptococcus uberis, Staphylococcus aureus, and Escherichia coli were determined. In addition, the bactericidal kinetics of $\mathrm{TC}$ on the aforementioned pathogens and the persistence of the antimicrobial activity of TC in milk over a period of 2 wk were investigated. All 4 plant-derived molecules exhibited antimicrobial activity against the 5 mastitis pathogens tested, but TC was most effective in killing the bacteria. The MIC and MBC of TC on Staph. aureus, E. coli, and Strep. uberis were 0.1 and $0.45 \%$, respectively, whereas that on Strep. agalactiae and Strep. dysgalactiae were 0.05 and $0.4 \%$, respectively. The MIC and $\mathrm{MBC}$ of the other 3 molecules ranged from 0.4 to $0.8 \%$ and 0.8 to $1.5 \%$, respectively. In time-kill assays, $\mathrm{TC}$ at the $\mathrm{MBC}$ reduced the bacterial pathogens in milk by 4.0 to $5.0 \log _{10} \mathrm{cfu} / \mathrm{mL}$ and to undetectable levels within 12 and $24 \mathrm{~h}$, respectively. The antimicrobial effect of TC persisted for the duration of the experiment (14 d) without any loss of activity. Results of this study suggest that TC has the potential to be evaluated as an alternative or adjunct to antibiotics as intramammary infusion to treat bovine mastitis.
\end{abstract}

Key words: mastitis, trans-cinnamaldehyde, antimicrobial

\section{INTRODUCTION}

Bovine mastitis is an inflammatory condition of mammary gland most often caused by bacterial intramammary infection, resulting in significant economic losses

Received May 22, 2008.

Accepted November 14, 2008

${ }^{1}$ Corresponding author: Kumar.venkitanarayanan@uconn.edu to the dairy industry. The increased production costs associated with mastitis can be attributed to culling, medication, discarded milk, and reduced milk quality (Natzke, 1981). The economic losses due to mastitis in the United States and worldwide have been estimated at US $\$ 2$ billion (Ott, 1999) and $\$ 35$ billion (Wellenberg et al., 2002), respectively. Based on the bacteriological etiologic agent, mastitis can be classified into contagious and environmental mastitis. An infected quarter is the source of contagious pathogens such as Staphylococcus aureus and Streptococcus agalactiae, whereas environmental pathogens such as Escherichia coli, Streptococcus dysgalactiae, and Streptococcus uberis originate from a variety of sources including bedding, manure, pastures, and pond water. Bacteria gain access to a healthy gland most frequently during and after the milking process, when vacuum fluctuations, liner slips, and relaxed teat canal sphincter muscle tone afford the greatest opportunity for invasion.

Intramammary infusion of antibiotics is the most common treatment method available for treating mastitis. However, the cure rates obtained with antibiotics are generally poor and vary for different mastitis pathogens. For example, the cure rates of mastitis caused by Staph. aureus range from 20 to $75 \%$ (Eberhart et al., 1987; Dingwell et al., 2003). Use of antibiotics against bacterial diseases in cattle, including mastitis, may potentially lead to the emergence of antibiotic resistant strains of bacteria (Berghash et al., 1983; White, 1999). Moreover, the use of antibiotics to treat bovine mastitis has been implicated as a common source of drug residues in milk (Erskine, 1996). Approximately $90 \%$ of the residues detected in milk over a period of $5 \mathrm{yr}$ in Michigan originated from antibacterial therapy for mastitis (Erskine et al., 2003). In light of the aforementioned problems and concerns, there is a need for alternative approaches for controlling mastitis in dairy cows.

Plant-derived essential oils represent a group of natural antimicrobials that have been traditionally used to preserve foods as well as enhance food flavor. The antimicrobial properties of several plant-derived essential oils have been demonstrated (Bilgrami et al., 1992; Burt, 2004; Holley and Patel, 2005), and a variety of 
active components of these oils have been identified. Trans-cinnamaldehyde (TC) is an aromatic aldehyde present as a major component of bark extract of cinnamon (Cinnamomum verum). Carvacol and thymol are antimicrobial ingredients in oregano oil obtained from Origanum glandulosum (Bendahou et al., 2008). Similarly, eugenol is an active ingredient in the oil from cloves (Eugenia caryophillis; Ali et al., 2005). All the aforementioned substances are classified as GRAS (generally regarded as safe) by the United States Food and Drug Administration. Moreover, plant-derived antimicrobials have been reported not to induce resistance in gram-positive and gram-negative bacteria after prolonged exposure (Ohno et al., 2003; Domadia et al., 2007).

Because dry cow therapy (DCT) is a common strategy for controlling mastitis, we investigated the antimicrobial properties of TC, eugenol, carvacrol, and thymol in milk for future application as a DCT in cows. Upon entry into the mammary gland through the teat canal, pathogens come in contact with milk, where they need to adapt, survive, and replicate before establishing an infection (Lammers et al., 2000). Moreover, milk is a complex medium in which lipophilic proteins such as albumin, and other nutrients, including fat and starch, can potentially interact with the antimicrobial molecules, thereby reducing their bioavailability. Therefore, milk was chosen as the in vitro model for studying the antimicrobial potential of TC, eugenol, carvacrol, and thymol for controlling mastitis.

The objective of this study was to determine the efficacy of TC, eugenol, carvacrol, and thymol for killing the major bacterial mastitis pathogens in milk. Specifically, the antimicrobial effect of the aforementioned plant-derived antimicrobials was investigated on Staph. aureus, Strep. agalactiae, Strep. dysgalactiae, Strep. uberis, and E. coli.

\section{MATERIALS AND METHODS}

\section{Maintenance and Preparation of Bacterial Cultures}

Three isolates each of Staph. aureus (DTSL-35, 17, and 38), Strep. agalactiae (DTSL-45, 41, and 7), Strep. dysgalactiae (DTSL-34, 20, and 28), Strep. uberis (DTSL-31, 27, and 19), and E. coli (DTSL-2, 39, and 40) isolated from clinical bovine mastitis cases were obtained from the University of Connecticut Diagnostic Testing Services Laboratory. All bacteriological media used in the study were purchased from Difco, Becton Dickinson (Sparks, MD). The purity of each culture was ensured by characteristic morphology on mannitol salt agar (Staph. aureus), sorbitol MacConkey agar (E. coli), or blood agar (streptococci). For preparation of inocula, each isolate of the pathogen was grown separately in $10 \mathrm{~mL}$ of tryptic soy broth (TSB) for $24 \mathrm{~h}$ at $37^{\circ} \mathrm{C}$. The cells were then sedimented by centrifugation $\left(3,600 \times g\right.$ for $15 \mathrm{~min}$ at $\left.4^{\circ} \mathrm{C}\right)$, washed twice with sterile PBS (pH 7.2), and resuspended in PBS. Equal portions from each of the 3 isolates were combined to make a 3 -isolate mixture of each species of the pathogen. The bacterial concentrations $(\mathrm{cfu} / \mathrm{mL})$ in the individual and 3 -isolate mixtures were determined by plating $0.1-\mathrm{mL}$ portions of appropriate dilutions on tryptic soy agar (TSA) plates, and incubating the plates at $37^{\circ} \mathrm{C}$ for $24 \mathrm{~h}$. Appropriate dilutions of the 3-isolate mixture in PBS were used to obtain the desired level of inoculum.

\section{Sample Preparation}

Fresh, raw milk free from antibiotic residues was collected from the bulk tank at the University of Connecticut dairy farm and autoclaved at $121^{\circ} \mathrm{C}$ and 103.4 $\mathrm{kPa}$ of pressure for $15 \mathrm{~min}$.

\section{Antimicrobials}

Trans-cinnamaldehyde (\# 239968), eugenol (\# 46100), carvacrol (\# 282197), and thymol (\# T0501) were purchased from Sigma-Aldrich Chemical Co. (St Louis, MO).

\section{Determination of MIC and Minimum Bactericidal Concentration}

The MIC and minimum bactericidal concentration (MBC) of TC, eugenol, carvacrol, and thymol against each bacterial pathogen were determined by the broth dilution assay described by Andrews (2001). Milk tubes containing TC, eugenol, carvacrol, or thymol in the range of 0 to $1.5 \%$ ( $\mathrm{vol} / \mathrm{vol}$ ) in increments of $0.05 \%$ were inoculated separately with each bacterial pathogen at $6.0 \log _{10} \mathrm{cfu} / \mathrm{mL}$ and incubated at $39^{\circ} \mathrm{C}$ for 24 h. Control samples included milk inoculated with each pathogen. Following incubation, the samples were serially diluted (1:10) in PBS and appropriate dilutions were plated on TSA plates. The plates were incubated at $37^{\circ} \mathrm{C}$ for $24 \mathrm{~h}$. The lowest concentration of the antimicrobial treatment that inhibited visible growth of the pathogen after incubation was taken as the MIC of the treatment. The lowest concentration of the treatment that prevented growth of the organism after subculture on TSA following serial dilution and plating was taken as the MBC. Triplicate samples were included for each treatment, and the experiment was replicated 3 times. 


\section{Time-Kill Assay}

The bactericidal kinetics of TC were studied by inoculating sterile milk containing the MIC (0.1\%), MBC $(0.4 \%)$, or a concentration greater than the MBC $(0.7 \%)$ of TC with each pathogen at $6.0 \log _{10} \mathrm{cfu} / \mathrm{mL}$. The concentration of $0.7 \%$ TC was chosen based on preliminary experiments in which it was found to be the lowest concentration above the MBC that brought about rapid killing of all pathogens. Control samples containing inoculated milk with no added antimicrobial were also included. The samples were incubated at $39^{\circ} \mathrm{C}$ for $24 \mathrm{~h}$ to replicate the cow's body temperature. Surviving populations of each bacterial pathogen were enumerated at $0,6,12$, and $24 \mathrm{~h}$ of incubation by plating $0.1-\mathrm{mL}$ portions of the samples directly or after serial dilutions (1:10 in PBS) on duplicate TSA plates. Pathogens that were not detected by direct plating were tested for surviving bacteria by enriching $1 \mathrm{~mL}$ of the sample in $100 \mathrm{~mL}$ of TSB at $39^{\circ} \mathrm{C}$ for $24 \mathrm{~h}$. When growth was observed in the broth, the culture was streaked on TSA plates and observed for typical colonies of each pathogen. Each treatment was done in duplicate, and the experiment was replicated 3 times.

\section{Determination of Persistence of Antimicrobial Activity of TC in Milk}

Milk samples containing $0.45 \%$ (MBC) or $0.7 \%$ of TC were inoculated with a 3-strain mixture of Staph. aureus at $6.0 \log _{10} \mathrm{cfu} / \mathrm{mL}$ and incubated at $39^{\circ} \mathrm{C}$ for $14 \mathrm{~d}$. Inoculated milk samples containing no TC served as controls. The surviving bacteria were determined immediately after TC addition and at 24-h intervals until d 14. To mimic the bacterial invasion of mammary gland after TC infusion, approximately $6.0 \log _{10} \mathrm{cfu} /$ $\mathrm{mL}$ of Staph. aureus was inoculated into the same milk samples every $48 \mathrm{~h}$ until d 6 (d 2, 4, and 6 ) and bacterial populations were determined on TSA after $24 \mathrm{~h}$. Duplicate samples were inoculated and the experiment was replicated 3 times.

\section{Determination of $\mathrm{pH}$}

Approximately $5 \mathrm{~mL}$ of milk was transferred into 20$\mathrm{mL}$ tubes. This was followed by the addition of various antimicrobial molecules and the $\mathrm{pH}$ was immediately determined (Accumet pH meter, Fisher Scientific, Fair Lawn, NJ).

\section{Statistical Analysis}

Time-Kill Assay. Bacterial counts (log values) from each pathogen were analyzed separately using PROC
MIXED (SAS Institute, Cary, NC). The model statement partitioned variation due to compound concentration, sample time, experiment replicate and concentration $\times$ time interaction. The REPEATED statement was used to indicate that samples within replicate $x$ concentration interaction were collected from the same tube. Data are expressed as least squares means.

Persistency Determination. Data from persistency determination experiments were analyzed similarly to the method used for time-kill assays. Data from 3 independent replicate experiments were analyzed using PROC MIXED (SAS Institute). The model statement partitioned variation due to TC concentration, sample time, experiment replicate, and concentration $\times$ time interaction. The REPEATED statement was used to indicate that samples within replicate $\times$ concentration interaction were collected from the same tube. Data are expressed as least squares means.

\section{RESULTS}

The average $\mathrm{pH}$ of milk and milk with the addition of antimicrobial molecules ranged from 6.60 to 6.67 . The MIC and MBC of TC, eugenol, carvacrol, and thymol on the mastitis pathogens are provided in Table 1. There was no variation in the $\mathrm{MIC}$ and $\mathrm{MBC}$ values among replicate samples. Among the 4 molecules tested, TC was most effective in killing all the mastitis pathogens tested. The MIC and MBC of TC on Staph. aureus, E. coli, and Strep. uberis were 0.1 and $0.45 \%$, respectively, whereas that on Strep. agalactiae and Strep. dysgalactiae were 0.05 and $0.4 \%$, respectively. The MIC and $\mathrm{MBC}$ of other 3 molecules ranged from 0.4 to $0.8 \%$ and from 0.8 to $1.5 \%$, respectively.

The bactericidal kinetics of $\mathrm{TC}$ on the mastitis pathogens in milk are depicted in Figure 1, panels A to E. The average initial bacterial population in all the treatment and control samples for the 5 mastitis pathogens was approximately $6.0 \log _{10} \mathrm{cfu} / \mathrm{mL}$. In the control samples, the bacterial population increased during the 24-h incubation period, reaching about $8.5 \log _{10} \mathrm{cfu} /$ $\mathrm{mL}$. However, in the treatment samples containing TC at $\mathrm{MBC}$ and $>\mathrm{MBC}$, the bacterial counts of all the pathogens were reduced substantially $(P<0.001)$. The presence of TC at MBC reduced the bacterial population by 4.0 to $5.0 \log 10 \mathrm{cfu} / \mathrm{mL}$ and to undetectable levels in 6 and $24 \mathrm{~h}$, respectively. However, the concentration of TC above the MBC completely inactivated all bacterial pathogens by $12 \mathrm{~h}$ of incubation, except Strep. uberis, in which an approximately $5.0 \log _{10} \mathrm{cfu} /$ $\mathrm{mL}$ kill was observed. As expected, for all bacteria, TC at MIC concentration did not allow growth to occur.

The results from the experiment determining the persistence of antimicrobial activity of TC in milk are 
Table 1. Minimum inhibitory concentration and minimum bactericidal concentration (MBC) of trans-cinnamaldehyde (TC), eugenol, carvacrol, and thymol against Staphylococcus aureus, Escherichia coli, Streptococcus agalactiae, Streptococcus dysgalactiae, and Streptococcus uberis (expressed in percentage)

\begin{tabular}{|c|c|c|c|c|c|c|c|c|}
\hline Pathogen & \multicolumn{2}{|c|}{$\mathrm{TC}$} & \multicolumn{2}{|c|}{ Eugenol } & \multicolumn{2}{|c|}{ Carvacrol } & \multicolumn{2}{|c|}{ Thymol } \\
\hline Staph. aureus & 0.1 & 0.45 & 0.6 & 1.4 & 0.5 & 1.2 & 0.6 & 1.2 \\
\hline Strep. agalactiae & 0.05 & 0.4 & 0.4 & 0.8 & 0.4 & 0.8 & 0.4 & 0.9 \\
\hline Strep. dysgalactiae & 0.05 & 0.4 & 0.4 & 0.4 & 0.4 & 0.8 & 0.4 & 0.9 \\
\hline Strep. uberis & 0.1 & 0.45 & 0.5 & 0.4 & 0.8 & 1.2 & 0.6 & 1.4 \\
\hline
\end{tabular}

depicted in Figure 2. Staphylococcus aureus $\left(6.0 \log _{10}\right.$ $\mathrm{cfu} / \mathrm{mL})$ inoculated in the milk samples on $\mathrm{d} 0$ were completely inactivated by $0.7 \%$ TC after $24 \mathrm{~h}$. On d 2 , $6.0 \log _{10} \mathrm{cfu} / \mathrm{mL}$ of Staph. aureus reinoculated into the milk samples was reduced to $<1.0 \log _{10} \mathrm{cfu} / \mathrm{mL}$ on $\mathrm{d}$ 3. On d 4, a similar reduction in Staph. aureus counts $\left(>5.0 \log _{10} \mathrm{cfu} / \mathrm{mL}\right)$ was observed after $24 \mathrm{~h}$. This trend in bacterial reduction was observed on the subsequent days, where $6.0 \log _{10} \mathrm{cfu} / \mathrm{mL}$ of Staph. aureus inoculated on d 6 was decreased to undetectable levels on d 12 of the experiment. A similar trend in Staph. aureus inactivation was also observed in milk samples containing $0.45 \% \mathrm{TC}$, but the magnitude of killing was slightly less than that observed with $0.70 \%$ TC. In control samples, the bacterial population increased to approximately 8.0 $\log _{10} \mathrm{cfu} / \mathrm{mL}$ by $24 \mathrm{~h}$, and remained at that level for the duration of the experiment.

\section{DISCUSSION}

Mastitis continues to be the single most expensive health-related problem confronting the dairy industry worldwide (Hortet and Seegers, 1998). Based on previous studies and the recommendations of the National Mastitis Council, DCT is considered to be one of the most effective methods for preventing mastitis during the dry period (Eberhart, 1986; Schukken et al., 1993). Given the various arguments that discourage widespread antibiotic use, development of alternative strategies using compounds not subject to limitations associated with antibiotics is needed. Herein, we present data indicating the efficacy of several plant-derived compounds for killing mastitis pathogens in vitro.

Antibacterial activity of several plant-derived molecules, including carvacrol, thymol, eugenol, and TC have been demonstrated against both gram-positive and gram-negative pathogens (Burt, 2004). For example, the antibacterial activity of $\mathrm{TC}$ has been reported against Clostridium botulinum (Bowles and Miller, 1993), Staph. aureus (Bowles et al., 1995), E. coli O157:H7, and Salmonella Typhimurium (Helander et al., 1998) in synthetic laboratory media. Similarly, the inhibi- tory effect of carvacrol and thymol against a variety of pathogens such as Salmonella Typhimurium (Si et al., 2006), E. coli O157:H7 (Burt et al., 2005), Campylobacter jejuni, and Listeria monocytogenes (Friedman et al., 2002) has been demonstrated. Eugenol is another plant-derived molecule reported to possess a wide spectrum of antimicrobial activity against gram-positive and gram-negative pathogens (Gill and Holley, 2004; Gaysinsky et al., 2007). Although considerable information is available on the antimicrobial properties of essential oils, most studies determining the antimicrobial activity of essential oils have been carried out in model broth systems (Knight and McKellar, 2007). Several studies have reported a decreased antimicrobial effect of plant extracts when used in foods or complex systems (Shelef et al., 1984; Stecchini et al., 1993; Pandit and Shelef, 1994; Gaysinsky et al., 2007). The concentrations of plant-derived molecules needed to achieve antimicrobial activity in complex foods such as meat, fish, dairy products, and vegetables are significantly greater than that needed in laboratory media (Burt, 2004). Similarly, Gaysinsky et al. (2007), while evaluating the antimicrobial effect of eugenol in milk, reported that milk composition, especially fat level, reduces the efficacy of the molecule. In light of these findings, we determined the MIC of MBC of the various molecules against the mastitis pathogens directly in milk rather than in any synthetic laboratory medium.

Because plant-derived molecules contain several different chemical groups in their structure, their antimicrobial activity is not attributable to one specific mechanism (Skandamis et al., 2001; Carson et al., 2002). A critical property of essential oils or their components is their hydrophobicity, which helps them to target the lipid-containing bacterial cell membrane and mitochondria (Knobloch et al., 1986; Sikkema et al., 1994). This makes these membranes more permeable, leading to leakage of ions and other cell contents (Cox et al., 2000; Carson et al., 2002; Ultee et al., 2002). In addition to the effect on cell membranes, TC is also believed to kill bacteria by inhibiting energy generation and glucose uptake (Gill and Holley, 2004). Yet another 

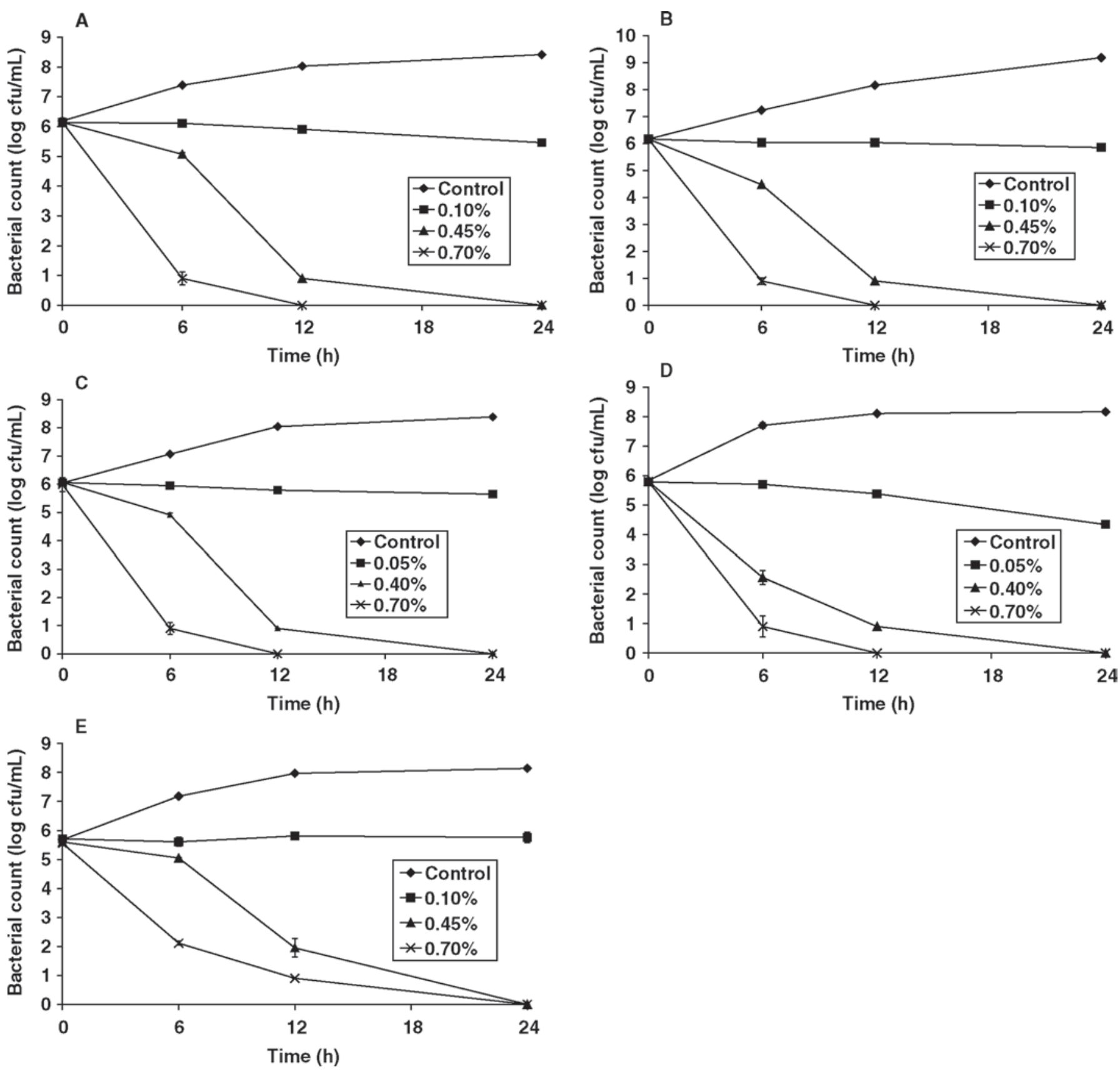

Figure 1. Inactivation of A) Staphylococcus aureus $(\mathrm{SEM}=0.052)$, B) Escherichia coli $(\mathrm{SEM}=0.039)$; C) Streptococcus agalactiae $(\mathrm{SEM}=$ $0.038)$; D) Streptococcus dysgalactiae (SEM = 0.083); and E) Streptococcus uberis (SEM = 0.091) in milk containing 0\% (control, $\bullet$ ), 0.1\% ( $\mathbf{\square})$, $0.45 \%(\boldsymbol{\Lambda})$, and $0.7 \%(\times)$ trans-cinnamaldehyde.

mechanism by which cinnamon oil and its components kill microorganisms is by their inhibitory effect on enzymes such as amino acid decarboxylases (Wendakoon and Sakaguchi, 1995).

Although all the 4 plant-derived molecules exhibited antimicrobial activity against the 5 mastitis pathogens tested, TC was found to be most effective in killing the bacteria. As is evident in Table 1, the MIC and MBC of TC were the lowest for all the mastitis pathogens compared with the other 3 molecules. Therefore, TC was selected for further studies. To be an effective antimicrobial as a DCT under field conditions, TC should maintain its antimicrobial activity over an extended period. However, the MIC and MBC experiments and time-kill assay determined the antimicrobial activity of TC in milk only up to $24 \mathrm{~h}$. Moreover, TC could be 


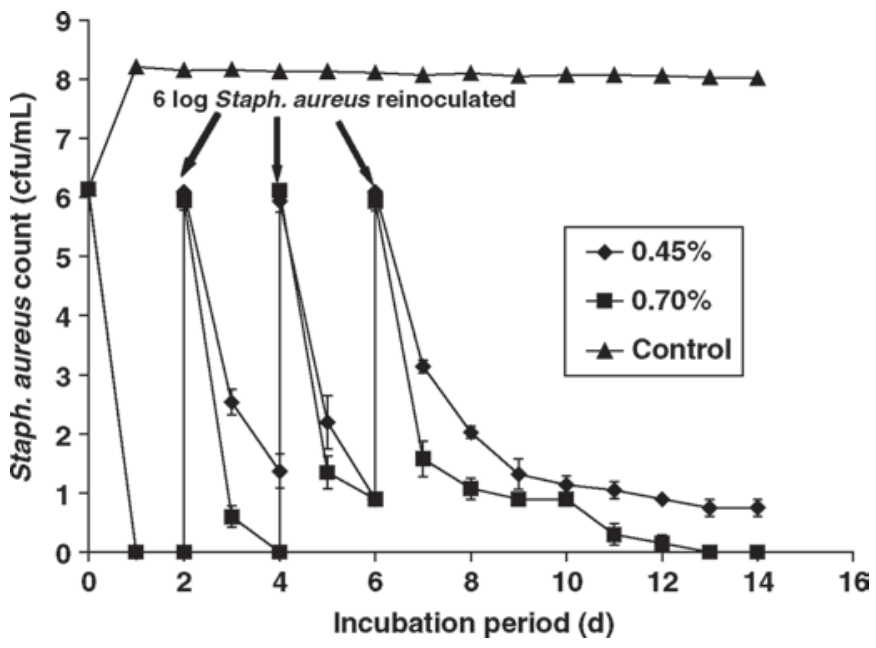

Figure 2. Persistence of antimicrobial activity of trans-cinnamaldehyde on Staphylococcus aureus in milk containing ( $) 0.45 \%$ and ( $0.7 \%$ trans-cinnamaldehyde.

degraded or inactivated in milk over a period of time. Therefore, we determined the persistence of antimicrobial activity of TC on Staph. aureus in milk for $14 \mathrm{~d}$ to confirm if TC could maintain antimicrobial activity over this period. Staphylococcus aureus was chosen for this experiment because Staph. aureus (along with $E$. coli and S. uberis) required the highest $\mathrm{MIC}$ and $\mathrm{MBC}$ of TC compared with the other pathogens. Moreover, Staph. aureus is more commonly associated with contagious mastitis than the other species (Makovec and Ruegg, 2003). The period of $14 \mathrm{~d}$ was chosen because the endogenous protection mechanism of keratin plug formation in teat canal takes about 10 to $14 \mathrm{~d}$ during drying off of cows (Bitman et al., 1991; Williamson et al., 1995). Moreover, the invasion of pathogens into the mammary gland could occur multiple times after the intramammary infusion of antimicrobials.

Therefore, to investigate whether TC would maintain its effectiveness over a period of time in a milk environment, Staph. aureus was reinoculated into the milk samples on d 2, 4, and 6 of the experiment after the addition of TC on d 0. As observed in Figure 2, the antimicrobial effect of TC persisted for the duration of the experiment without any loss of activity. It was also found that TC added to milk on d 0 was effective in killing large populations of Staph. aureus inoculated multiple times on subsequent days.

Results from this study suggest that TC may be useful as an alternative or adjunct to antibiotics for use in DCT to control mastitis. In fact, given the antimicrobial activity documented herein, TC may also be useful in controlling mastitis during lactation. However, future experiments are needed to determine the pharmacoki- netics of TC in bovine mammary gland studies, and to ascertain the in vivo efficacy of this molecule for treating bovine mastitis as an intramammary treatment, in addition to its potential effect on the mammary gland tissue.

\section{REFERENCES}

Ali, S. M., A. A. Khan, I. Ahmed, M. Musaddiq, K. S. Ahmed, H. Polasa, V. L. Rao, C. M. Habibullah, L. A. Sechi, and N. Ahmed. 2005. Antimicrobial activities of eugenol and cinnamaldehyde against the human gastric pathogen Helicobacter pylori. Ann. Clin. Microbiol. Antimicrob. 4:20-26.

Andrews, J. M. 2001. Determination of minimum inhibitory concentrations. J. Antimicrob. Chemother. 48:5-16.

Bendahou, M., A. Muselli, M. Grignon-Dubois, M. Benyoucef, J. Desjobert, A. Bernardini, and J. Costa. 2008. Antimicrobial activity and chemical composition of Origanum glandulosum Desf. essential oil and extract obtained by microwave extraction: Comparison with hydrodistillation. Food Chem. 106:132-139.

Berghash, S. R., J. N. Davidson, J. C. Armstrong, and G. M. Dunny. 1983. Effects of antibiotic treatment of nonlactating dairy cows on antibiotic resistance patterns of bovine mastitis pathogens. Antimicrob. Agents Chemother. 24:771-776.

Bilgrami, K. S., K. K. Sinha, and A. K. Sinha. 1992. Inhibition of aflatoxin production and growth of Aspergillus flavus by eugenol and onion and garlic extracts. Indian J. Med. Res. 96:171-175.

Bitman, J., D. L. Wood, S. A. Bright, R. H. Miller, A. V. Capuco, A. Roche, and J. W. Pankey. 1991. Lipid comparison of teat canal keratin collected before and after milking from Holstein and Jersey cows. J. Dairy Sci. 74:414-420.

Bowles, B. L., and A. J. Miller. 1993. Antibotulinal properties of selected aromatic and aliphatic aldehydes. J. Food Prot. 56:788794.

Bowles, B. L., S. K. Sackitey, and A. C. Williams. 1995. Inhibitory effects of flavor compounds on Staphylococcus aureus WRRC B124 . J. Food Saf. 15:337-347.

Burt, S. 2004. Essential oils: Their antibacterial properties and potential application in food-A review. Int. J. Food Microbiol. $94: 223-253$.

Burt, S. A., R. Vlielander, H. P. Haagsman, and E. J. Veldhuizen 2005. Increase in activity of essential oil components carvacrol and thymol against Escherichia coli O157:H7 by addition of food stabilizers. J. Food Prot. 8:919-926.

Carson, C. F., B. J. Mee, and T. V. Riley. 2002. Mechanism of action of Melaleuca alternifolia (tea tree) oil on Staphylococcus aureus determined by time-kill, lysis, leakage and salt tolerance assays and electron microscopy. Antimicrob. Agents Chemother. 46:1914-1920

Cox, S. D., C. M. Mann, J. L. Markham, H. C. Bell, J. E. Gustafson, J. R. Warmington, and S. G. Wyllie. 2000. The mode of antimicrobial action of essential oil of Melaleuca alternifola (tea tree oil). J. Appl. Microbiol. 88:170-175.

Dingwell, R. T., K. E. Leslie, T. F. Duffield, Y. H. Schukken, L. DesCoteaux, G. P. Keefe, D. F. Kelton, K. D. Lissemore, W. Shewfelt, P. Dick, and R. Bagg. 2003. Efficacy of intramammary tilmicosin and risk factors for cure of Staphylococcus aureus infection in the dry period. J. Dairy Sci. 86:159-168.

Domadia, P., S. Swarup, A. Bhunia, J. Sivaraman, and D. Dasgupta. 2007. Inhibition of bacterial cell division protein FtsZ by cinnamaldehyde. Biochem. Pharmacol. 832:831-840.

Eberhart, R. J. 1986. Management of dry cows to reduce mastitis. J. Dairy Sci. 69:1721-1732.

Eberhart, R. J., R. J. Harmon, D. E. Jasper, R. P. Natzke, S. C. Nickerson, J. K. Reneau, E. H. Row, K. L. Smith, and S. B. Spencer. 1987. Current Concepts of Bovine Mastitis. 3rd ed. Natl. Mastitis Counc., Arlington, VA.

Erskine, R. J. 1996. Why do antibiotic residues in milk happen? Michigan Dairy Rev. 1:16. 
Erskine, R. J., S. Wagner, and F. J. DeGraves. 2003. Mastitis therapy and pharmacology. Vet. Clin. North Am. Food Anim. Pract. 19:109-138.

Friedman, M., P. R. Henika, and R. E. Mandrell. 2002. Bactericidal activities of plant essential oils and some of their isolated constituents against Campylobacter jejuni, Escherichia coli, Listeria monocytogenes, and Salmonella enterica. J. Food Prot. $65: 1545-1560$.

Gaysinsky, S., T. M. Taylor, P. M. Davidson, B. D. Bruce, and J. Weiss. 2007. Antimicrobial efficacy of eugenol microemulsions in milk against Listeria monocytogenes and Escherichia coli O157:H7. J. Food Prot. 70:231-237.

Gill, A. O., and R. A. Holley. 2004. Mechanisms of bactericidal action of cinnamaldehyde against Listeria monocytogenes and of eugenol against L. monocytogenes and Lactobacillus sakei. Appl. Environ. Microbiol. 70:5750-5755.

Helander, I. M., H. L. Alakomi, K. Latva-Kala, T. Mattila-Sandholm, I. Pol, E. J. Smid, L. G. M. Gorris, and A. Von Wright. 1998. Characterization of the action of selected essential oil components on gram-negative bacteria. J. Agric. Food Chem. 46:3590-3595.

Holley, R. A., and D. Patel. 2005. Improvement in shelf-life and safety of perishable foods by plant essential oils and smoke antimicrobials. Food Microbiol. 22:273-292.

Hortet, P., and H. Seegers. 1998. Loss in milk yield and related composition changes resulting from clinical mastitis in dairy cows. Prev. Vet. Med. 37:1-20.

Knight, K. P., and R. C. McKellar. 2007. Influence of cinnamon and clove essential oils on the D- and z-values of Escherichia coli O157:H7 in apple cider. J. Food Prot. 70:2089-2094.

Knobloch, K., H. Weigand, N. Weis, H. M. Schwarm, and H. Vigenschow. 1986. Action of terpenoids on energy metabolism. Pages 429-445 in Progress in Essential Oil Research: 16th International Symposium on Essential Oils. E. J. Brunke, ed. De Gruyter, Berlin, Germany.

Lammers, A., E. Kruijt, C. Van de Kuijt, P. J. M. Nuijten, and H. E. Smith. 2000. Identification of Staphylococcus aureus genes expressed during growth in milk: A useful model for selection of genes important in bovine mastitis? Microbiology 146:981-987.

Makovec, J. A., and P. L. Ruegg. 2003. Results of milk samples submitted for microbiological examination in Wisconsin from 1994-2001. J. Dairy Sci. 86:3466-3472.

Natzke, R. P. 1981. Elements of mastitis control. J. Dairy Sci. 64:1431-1442.

Ohno, T., M. Kita, Y. Yamaoka, S. Imamura, T. Yamamoto, S. Mitsufuji, T. Kodama, K. Kashima, and J. Imanishi. 2003. Antimicrobial activity of essential oils against Helicobacter pylori. Helicobacter 8:207-215.
Ott, S. 1999. Costs of herd-level production losses associated with subclinical mastitis in US dairy cows. Pages 152-156 in Proc. 38th Annu. Mtg. National Mastitis Council, Arlington VA. Natl. Mast. Counc., Madison WI.

Pandit, V. A., and L. A. Shelef. 1994. Sensitivity of Listeria monocytogenes to rosemary (Rosmarinus officinalis L.). Food Microbiol. 11:57-63.

Schukken, Y. H., J. Vanvliet, D. Vandegeer, and F. J. Grommers. 1993. A randomized blind trial on dry cow antibiotic infusion in a low somatic cell count herd. J. Dairy Sci. 76:2925-2930.

Shelef, L. A., E. K. Jyothi, and M. A. Bulgarelli. 1984. Growth of enteropathogenic and spoilage bacteria in sage-containing broth and foods. J. Food Sci. 49:737-740

Si, W., J. Gong, C. Chanas, S. Cui, H. Yu, C. Caballero, and R. M. Friendship. 2006. In vitro assessment of antimicrobial activity of carvacrol, thymol and cinnamaldehyde towards Salmonella serotype Typhimurium DT104: Effects of pig diets and emulsification in hydrocolloids. J. Appl. Microbiol. 101:1282-1291.

Sikkema, J., J. A. M. De Bont, and B. Poolman. 1994. Interactions of cyclic hydrocarbons with biological membranes. J. Biol. Chem. 269:8022-8028.

Skandamis, P., K. Koutsoumanis, K. Fasseas, and G. J. E. Nychas. 2001. Inhibition of oregano essential oil and EDTA on Escherichia coli O157:H7. Ital. J. Food Sci 13:65-75.

Stecchini, M. L., I. Sarais, and P. Giavedoni. 1993. Effect of essential oils on Aeromonas hydrophila in a culture medium and in cooked pork. J. Food Prot. 56:406-409.

Ultee, A., M. H. J. Bennink, and R. Moezelaar. 2002. The phenolic hydroxyl group of carvacrol is essential for action against the food-borne pathogen Bacillus cereus. Appl. Environ. Microbiol. 68:1561-1568.

Wellenberg, G. J., W. H. Van der Poel, and J. T. Van Oirschot. 2002. Viral infections and bovine mastitis: A review. Vet. Microbiol. $88: 27-45$.

Wendakoon, C. N., and M. Sakaguchi. 1995. Inhibition of amino acid decarboxylase activity of Enterobacter aerogenes by active components in spices. J. Food Prot. 58:280-283.

White, D. G. 1999. Use and misuse of antimicrobials in veterinary medicine. Page 9 in Proc. 38th Natl. Mastitis Counc. Ann. Mtg., Arlington, VA. Natl. Mastitis Counc. Inc., Madison, WI.

Williamson, J. H., M. W. Woolford, and A. M. Day. 1995. The prophylactic effect of a dry cow antibiotic against Streptococcus uberis. N. Z. Vet. J. 43:228-234. 